\title{
Phylogenetic Relationships of Nine Cultivars of Strawberries (Fragaria spp.) Based on Anatomical and Morphological Characters
}

DOI: 10.18196/pt.2017.072.116-126

\author{
Rina Sri Kasiamdari ${ }^{1 *}$, Ganies Riza Aristya ${ }^{2}$, Evi Inayati ${ }^{3}$ \\ ${ }^{1}$ Laboratory of Plant Systematics, Faculty of Biology, Universitas Gadjah Mada, \\ ${ }^{2}$ Laboratory of Genetics and Breeding, Faculty of Biology, Universitas Gadjah Mada, \\ ${ }^{3}$ Faculty of Biology, Universitas Gadjah Mada, Jl. Teknika Selatan, Sekip Utara Yogyakarta 55281 Indonesia, Telp. (0274) 580839, \\ *Corresponding author, email: rkasiamdari@ugm.ac.id
}

\begin{abstract}
Strawberry cultivation in Indonesia is centred at Citrus and Subtropical Fruit Research Institute, which collect different cultivars of Fragaria spp. Information on classification based on phenotypic characters of Fragaria spp. has not been studied as a whole. The purpose of the present study was to identify and determine phylogenic relationships of nine cultivars of strawberries based on the anatomical and morphological characters. The study identified morphologically nine strawberry cultivars by referring to the IPGRI (1986). Anatomical preparations of roots, stems and leaves were made by the embedding method. Phylogenetic relationships were determined using MVSP software with UPGMA algorithm through the Gower General Similarity Coefficient method. Subsequently, the principal components were analyzed using the Euclidian Biplots algorithm depicted in a Scatter plot. The phylogenetic relationship produced two clusters with $79 \%$ similarity index. The closely related cultivars were Festival and Rosa Linda with a similarity index of $94 \%$, and Earlibrite and Aerut with a similarity index of $86 \%$.

Keywords: Fragaria spp., Anatomical, Morphological, Phylogenetic relationships
\end{abstract}

\begin{abstract}
ABSTRAK
Balai Penelitian Jeruk dan Tanaman Sub-tropika merukan pusat budidaya stroberi yang ada di Indonesia. Informasi klasifikasi berdasarkan karakter fenotip Fragaria spp. belum dipelajari secara keseluruhan. Penelitian ini bertujuan untuk mengetahui klasifikasi dan hubungan kekerabatan beberapa kultivar stroberi berdasarkan karakter Anatomis dan Morfologis. Dalam penelitian ini dilakukan klasifikasi beberapa kultivar stroberi yang mengacu pada IPGRI (1986) dan UPOV (2012). Pembuatan preparat anatomis akar, batang dan daun dilakukan dengan metode penyelubungan (embedding). Hubungan kekerabatan ditentukan dengan menggunakan software MVSP dengan algoritma UPGMA melalui metode Gower General Similarity Coefficient. Selanjutnya dilakukan analisis komponen utama menggunakan algoritma Euclidian Biplots yang digambarkan dalam bentuk Scatter plot. Hasil penelitian dari sembilan kultivar yang diamati menunjukkan kultivar yang berkerabat dekat adalah Festival dan Rosa Linda pada indeks similaritas 94\% dan kultivar Earlibrite dan Aerut dengan indeks similaritas $86 \%$.

Kata kunci: Fragaria spp., Hubungan kekerabatan, Morfologis, Anatomis
\end{abstract}

\section{INTRODUCTION}

Strawberries (Fragaria spp.) are member of the Rosaceae family and native from Europe, which scattered almost all over the world including Indonesia (Santosa, 2011). Strawberry varieties which widely consumed and desired by the people community is a sweet, brightly colored, and large of strawberry variety. It is an opportunity for the farmers to develop strawberry cultivation techniques and improve the quality and quantity of strawberry production in Indonesia (Hancock, 1999).

The methods for determination of strawberry phylogenetic relationships is based on morphological and anatomical characters (Mauseth, 1988). The morphological characters of strawberry plant can be recognized as follows: it has 20-35 primary roots, short-segmented-jointed-herbaceous stem, covered leaves (Hofer et al., 2012). The stem is modified into a crown and has smaller branches called crown branches (Region, 2013). It's stolon creeps above the ground, the independently growing of which may soon be cut or separated from the parent clump as planting materials (Hummer and Jannick, 2009). The leaf 
is green, trifoliate and serrated, the entire surface of which is covered by trichomes (Region, 2013). The flowers are hermaphrodite, consists of 5-10 sepals, five crown petals, 20-35 stamens arranged in panicles. Each branching panicle has four types of flowers: one primary or terminal flower, the earliest blooming one; two secondary flowers; four tertiary flowers; and eight quaternary flowers (Region, 2013). False fruits come out of the enlarged receptacle, is conical to round in shape and stick to the base of the flower (Hummer \& Jannick, 2009). Bright to dark red fruits of $\pm 2.5-5 \mathrm{~cm}$ in size are aggregate fruits composed of several achenes (Budiman and Saraswati, 2005). Seeds are small occurring within the fruit flesh (Rukmana, 1998).

In a cross section, the structure of strawberry root and stem from the outside to the inside includes the epidermis and cortex, consisting of intercellular spaces with the outermost layer adjacent to the epidermis called the exodermis, capable of differentiation into hypodermis (Murti et al., 2012). The innermost layer of the cortex is composed of the endodermis capable of phellem thickening on the walls and forming dots called the Casparian dots resembling U-like shape. The innermost layer, stele, with is the outermost layer of the stele directly adjacent to the endodermis, is referred to as the pericycle. In addition to the pericycle, there is also the medulla as the innermost layer consisting of the parenchymal tissue. Medulla is surrounded by vascular tissues, consists of the xylem and phloem arranged alternately in the direction of the radius (Esau, 1977).

The anatomical structure of strawberry leaf generally includes the epidermis serving as preventing water loss from transpiration, regulating gas exchange, secreting metabolic compounds, and (in some species) absorbing water (Naseri and Tantawy, 2003). This layer occurs in two sections, on the surface facing upward (adaxial) and on the surface facing downward (abaxial). The mesophyll is composed of homogeneous parenchyma cells and differentiates into mass tissues or palisade parenchyma, as well as the vascular tissues consisting of xylem and phloem (Esau, 1977).

Variations in the strawberry plant are among the advantages of the plant, making it possible to create plant hybrids affected by the close phylogenetic relationships of several phenotypic appearances (Nielsen and Lovell, 2000). The higher the phenotypic similarity the closer the phylogenetic relationship is (Esau, 1977). The purpose of the present study was to determine the anatomical and morphological characters of nine cultivars of strawberries and to determine the phylogenetic relationships of nine cultivars of strawberries based on anatomical and morphological observation, as well as the specific characters of an important effect on the grouping of the nine cultivars of strawberries (Chandler et al., 2000).

\section{MATERIALS AND METHODS}

Collection of Strawberry Samples

Nine cultivars of strawberries were taken from Indonesian Citrus and Subtropical Fruit Research Institute, Malang, East Java. Each strawberry plant was subjected to data collection of the morphological characters of roots, stems, leaves, flowers and fruits with reference to the IPGRI (The International Plant Genetic Resources Institute) (1986), UPOV (International Union for the Protection of New Varieties of Plants) (2012) and Hofer et al. (2012) with some additional modifications.

\section{Making of Anatomical Preparations \\ Sample Cutting}

Fully developed roots, stems and leaves were selected. Root and stem samples were transversely cut $3 \mathrm{~cm}$ from the tip. Leaf samples were taken 
by transversely cutting leaves through the midrib. The collected samples of roots, stems and leaves were stored in flakon bottles containing $70 \%$ alcohol and labeled in accordance with the cultivar name.

\section{Embedding Method}

Samples were fixed using FAA (formaldehyde:glacial acetic acid:alcohol) solution with a ratio of $90 \mathrm{ml}: 5 \mathrm{ml}: 5 \mathrm{ml}$, respectively, and allowed to stand for $24 \mathrm{~h}$. It was then washed with $70 \%$ alcohol for $30 \mathrm{~min}$ and stained with $1 \%$ safranin in $70 \%$ alcohol for $24 \mathrm{~h}$. Samples were dehydrated in a graded alcohol series (70\%; 80\%; 95\%; 100\%, 100\%) and dealcoholized in a graded ratio of alcohol:xylol (v3:1; v1:1; v1:3; xylol; xylol). Subsequently, it was subjected to infiltration by removing the xylol:paraffin mixture and replacing it with pure paraffin at a temperature of $57^{\circ} \mathrm{C}$ for $24 \mathrm{~h}$ (Sutikno, 2014). Paraffin was replaced with new pure paraffin for one hour and samples were made into blocks. Samples were cut using a rotary microtome to make slices of 6-12 micrometer in thickness. The slices were fixed on an object glass with a glycerine:albumin mixture added with water and placed on a hot plate at a temperature of 45C. The slices were stained with $1 \%$ safranin in $70 \%$ alcohol and placed in a graded mixture of alcohol: xylol $(3: 1 ; 1: 1 ; 1: 3 ;$ xylol; xylol). It was covered with a glass lid with Canada Balsam and dried. The samples were labeled and annotated with the name of the species, organ, cross-section and date.

\section{Data analysis}

Descriptive analysis was performed by describing and identifying the vegetative and generative organs of the specimens through recording the morphological traits and characteristics. Numerical analysis was carried out by comparing the anatomical and morphological data and phylogenetic relationships were identified by means of cluster analysis.

\section{RESULTS AND DISCUSSIONS}

Based on the inventory of strawberries at the Citrus and Subtropical Fruit Research Institute, there were nine cultivars of strawberries which could be identified from the two Fragaria species, namely Fragaria vesca of Californica subspecies, and eight strawberry cultivars of $F$. anannassa Duchesne including Rosa Linda, Berastagi, Festival, Santung, Holland, Sweet Charlie, Aerut, and Earlibrite.

\section{Morphology}

Observations of 37 morphological characters of the roots, stems, leaves and fruit of the strawberry which referred to the IPGRI (The International Plant Genetic Resources Institute) (1986), UPOV (International Union for the Protection of New Varieties of Plants) (2012) and Hofer et al. (2012) with some additional modifications indicated 25 synthetic characters (the same character found on the nine cultivars observed) including, among others, the number of stems in a plant, the robustness of the plant, the ability to generate stolon, timing of stolon emergence, growth direction of stolon on the stems, type of leaf veins, presence or absence of trichomes on the lower and upper surface of leaves, presence or absence of variations in leaf color, leaf color, shape of the tip of the leaf, number of flowers in a plant, the location of flowers relative to plant, strength of receptacle, type of flower, petal color, presence or absence of a stigma, presence or absence of pollen, symmetry of flowers, fruit size, color of fruit flesh, robustness of fruit, density of achene. Additionally, those observations also indicated 12 diagnostic characters (different characters among the nine cultivars observed) in- 
cluding, among others, type of growth, leaf size, shape of leaf edges, shape of the leaf base, type of flower attachment, petal size relative to the crown, petal attachment to fruit, petal direction towards fruit, fruit shape, external color of the fruit and core color (Ryall and Lipton, 1972).

Morphological characters of the stem observed were the type of growth, the number of stems in a plant, robustness of the plant, ability to generate stolons, timing of stolon emergence and direction of hair growth on the stem (Figure 1).

The nine cultivars had a moderate number of stems in a plant ( $>3$ stems/plant), a moderate ability to generate stolon (>10 stolon/plant), a quite fast emergence of stolon, a horizontal growth direction of hairs on the stolon and high robustness of the plant. The character of plant robustness was influenced by the anatomical structure of the stem. This is due to the fact that strawberries are a dicotyledonous plant whose stems are subjected to secondary growth by having a lateral meristem. Additionally, the clustering life form of strawberries also supports the robustness of their stems.

Figure 2 showed a low degree of variations in the types of growth. Those variations in the types of growth included upright, intermediate and spreading referring to the UPOV (2012). The cultivars of strawberries with upright growth were Californica and Aerut, while those with intermediate growth were Rosa Linda, Berastagi, Festival, Santung, Holland, Sweet Charlie, and Earlibrite.

Figure 3 showed that those cultivars with rounded leaf base are Californica, Rosa Linda, Berastagi, Festival, Santung, Holland and Aerut. Those cultivars with obtuse leaf base were Sweet Charlie and Earlibrite with medium green leaves and varying sizes from small $(5-10 \mathrm{~cm})$ to medium $(10-15 \mathrm{~cm})$. Those cultivars with a small-sized leaves wereRosa Linda and Holland. Cultivars with medium-sized leaves were Californica, Berastagi, Festival, Santung, Sweet Charlie, Aerut and Earlibrite.

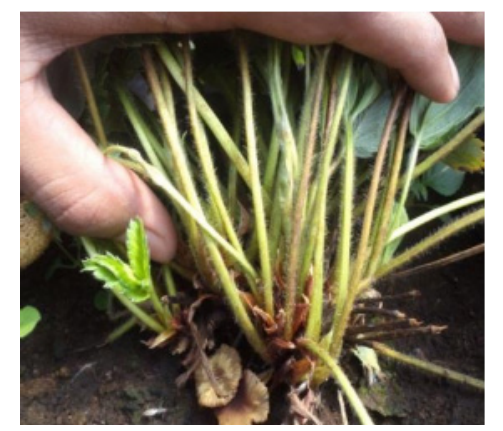

figure 1. Stems of strawberry plants

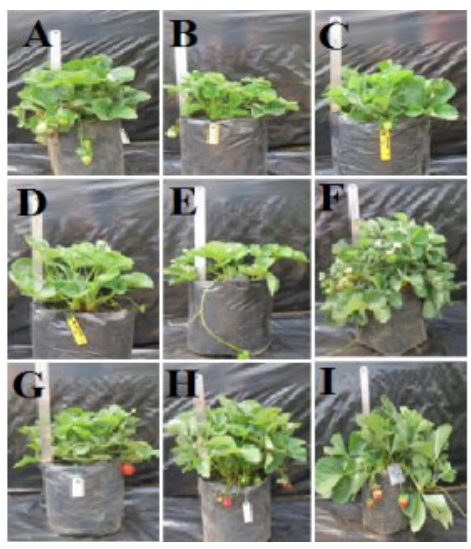

Figure 2. Types of growth of nine cultivars of strawberries. (A) Californica, (B) Rosa Linda, (C) Berastagi, (D) Festival, (E) Santung, (F) Holland, (G) Sweet Charlie, (H) Aerut, (I) Earlibrite. (Upright: A and $\mathrm{H}$; Intermediate: $\mathrm{B}-\mathrm{G}$ and I)

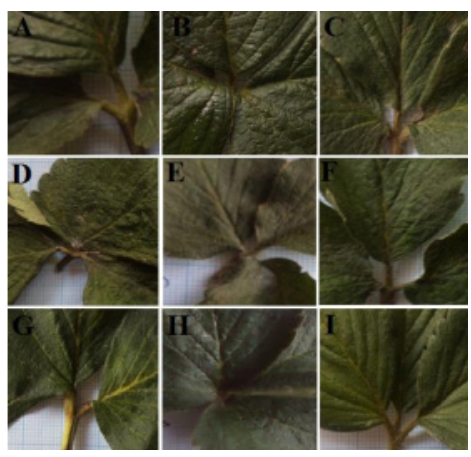

Figure 3. The shape of leaf base of nine cultivars strawberries; (A) Californica, (B) Rosa Linda, (C) Berastagi, (D) Festival, (E) Santung, (F) Holland, (G) Sweet Charlie, (H) Aerut, (I) Earlibrite. (Obtuse: $G$ and I; Rounded: A-F and $\mathrm{H}$ ) 
Figure 4 showed that the cultivar with serrated leaf edge was Holland; cultivars with intermediate leaf edge were Californica, Berastagi, Festival, Santung, Sweet Charlie, Aerut and Earlibrite; the cultivar with crenate leaf edge was Rosa Linda.

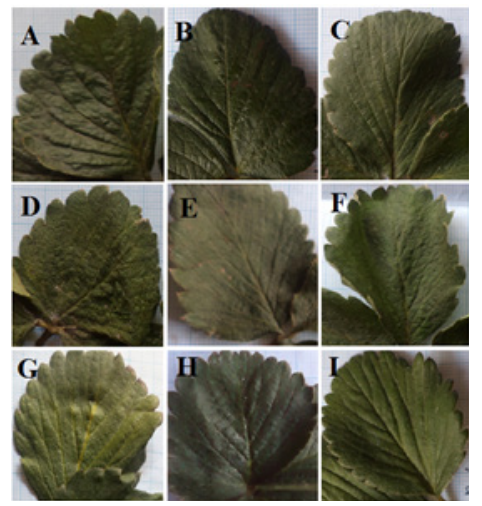

Figure 4. Shape of leaf edges of nine cultivars of strawberries; (A) Californica, (B) Rosa Linda, (C) Berastagi, (D) Festival, (E) Santung, (F) Holland, (G) Sweet Charlie, (H) Aerut, (I) Earlibrite. (Serrate: $F_{\text {; }}$ Crenate: B; Intermediate: A, C-E, G-I)

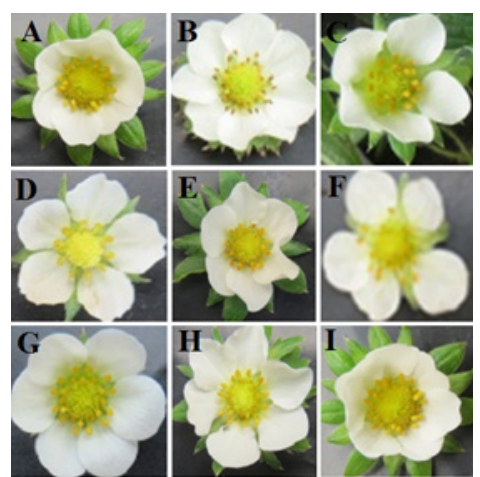

Figure 5. Types of attachment of crown; (free: B, D, $F$, Stacked: $A, C, E, G-1)$ and size of petal relative to the crown (smaller: G; equal: B, D, F; bigger: A, C, E, G-I) of nine cultivars of strawberries, (A) Californica, (B) Rosa Linda, (C) Berastagi, (D) Festival, (E) Santung, (F) Holland, (G) Sweet Charlie, (H) Aerut and (I) Earlibrite

Observations on morphological characters of flowers and fruit of the nine cultivars showed that those cultivars had moderate number of flowers in a plant, flowers located below the leaves, good strength of receptacle on the bud, hermaphrodite flowers, medium-sized fruits ( 3 $\mathrm{cm})$, bright red fruit flesh, moderate achene density, high robustness of fruits. These characters were not affected by the anatomical structure of the constituent fruits and stems.

Figure 5 showed that those cultivars with free attachment of flowers were Berastagi, Festival and Holland. Those cultivars with stacked crown are Californica, Rosa Linda, Santung, Sweet Charlie, Aerut and Earlibrite. The strawberry cultivar with petals smaller than the crown was Sweet Charlie, and those cultivars with petals equal to the crown were Rosa Linda, Festival and Holland. Cultivars with larger petals than the crown are Californica, Berastagi, Santung, Aerut and Earlibrite.

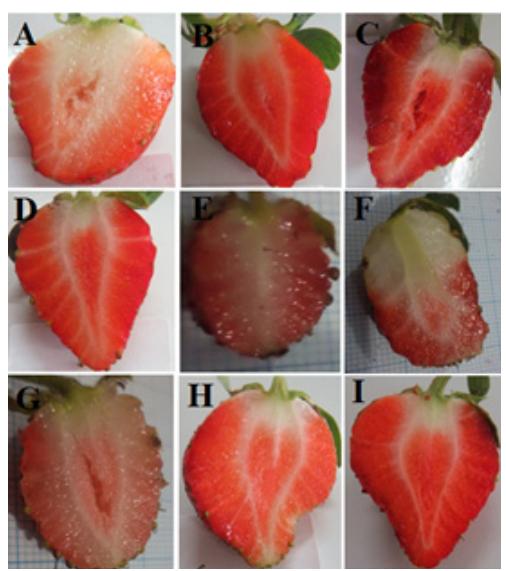

Figure 6. Core colors (white: A, F, G; bright red: $B-E, H-I$ ) and types of calyx attachment to the fruit (recessed: C; flat: A, B, D-E, G-l; protruded: F) of nine cultivars of strawberries; (A) Californica, (B) Rosa Linda, (C) Berastagi, (D) Festival, (E) Santung, (F) Holland, (G)

Sweet Charlie, (H) Aerut and (I) Earlibrite

Observations of the core colors of the nine cultivars studied showed low variations as indicated by the white and bright red colors. Cultivars with a white were Californica, Santung and Holland, and cultivars with a bright red core were Rosa Linda, Berastagi, Festival, Sweet Charlie, Aerut and Earlibrite (Figure 6). 
Observations of the fruit shapes of the nine cultivars studied showed variations that could be divided into four groups: ovoid, conical, cylindrical and cordate. Cultivars with ovoid fruits were Californica, Santung and Holland. Cultivars with conical fruits were Rosa Linda, Berastagi and Festival. The cultivar with cylindrical fruits was Sweet Charlie and cultivars with cordate fruits were Aerut and Earlibrite (Figure 7).

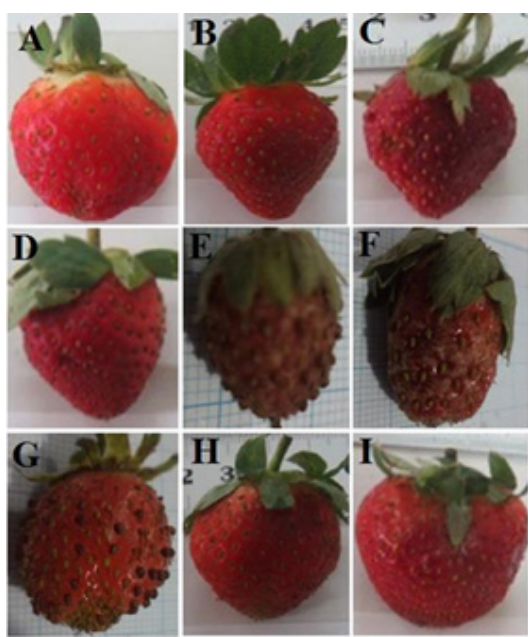

Figure 7. Fruit shapes (ovoid: $A, E, F$; cylindrical: G; conical: $\mathrm{R}, \mathrm{B}, \mathrm{F}$; cordate: $\mathrm{H}, \mathrm{I}$ ) and growth direction of petals relative to the fruit (upward: $C-A$; flat: $D-I$ ) of nine cultivars of strawberries, (A) Californica, (B) Rosa Linda, (C) Berastagi, (D) Festival, (E) Santung, (F) Holland, (G) Sweet Charlie, (H) Aerut and (I) Earlibrite

\section{Anatomy}

The present study observed anatomical characters of roots, stems and leaves. Strawberries are dicotyledonous plants with roots composed of epidermis, cortex and stele. Root epidermis consists of a layer of cells and contains no cuticle. In the epidermis a layer of root fibrous cells is found that is developed from the epidermal cells in region of apical meristem (Figure 8). Its functions are to absorb nutrients and hold the roots in the ground.

Table 1 showed that the cultivar with the largest diameter of root is Californica (1501.31 $\mathrm{m})$ and that with the smallest diameter of root is Berastagi $(774.73 \mu \mathrm{m})$. Calculation of the size of the cortical cells also showed similar results, with the largest cortical cell being Californica (58.64 $\mu \mathrm{m})$ and the smallest being Festival $(30.29 \mu \mathrm{m})$. Diameter of the root and size of cortical cells is closely related to metabolic processes affecting nutrient absorption and translocation of photosynthetic products. The larger the size of the cortical cells, the greater the diameter of the root is.

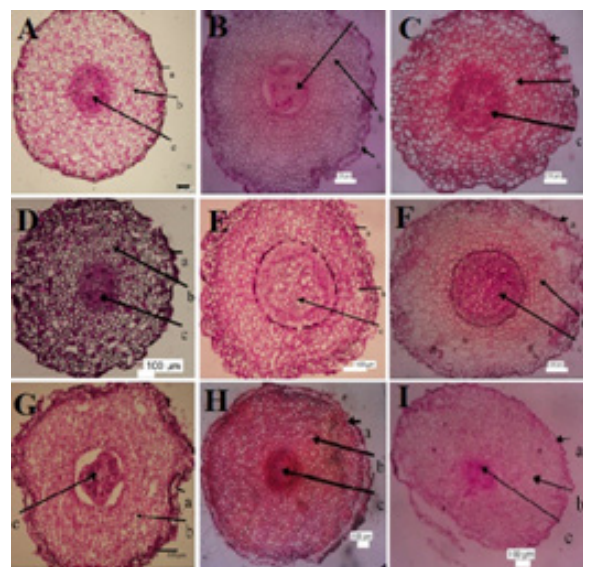

Figure 8. Cross-sections of the roots of Fragaria spp. of cultivars (A) Californica, (B) Rosa Linda, (C) Berastagi, (D) Festival, (E) Santung, (F) Holland, (G) Sweet Charlie, (H) Aerut and (I) Earlibrite with constituent tissues of (a) epidermis, (b) cortices and (c) stele. Bar scale: 100 $\mu \mathrm{m}$

Table 1. Mean Anatomical Structure of Roots of Nine Strawberry Cultivars

\begin{tabular}{lcc}
\hline Character Cultivar & Root Diameter & Size of Cortical Cells \\
\hline Californica & $1501.31 \pm 115.57^{\mathrm{a}}$ & $58.64 \pm 5.99^{\mathrm{a}}$ \\
Rosa Linda & $884.66 \pm 37.75^{\mathrm{def}}$ & $36.21 \pm 8.04^{\mathrm{cd}}$ \\
Berastagi & $774.73 \pm 70.67^{\mathrm{f}}$ & $39.20 \pm 8.95^{\mathrm{bcd}}$ \\
Festival & $771.95 \pm 75.89^{\mathrm{f}}$ & $30.29 \pm 12.59^{\mathrm{d}}$ \\
Santung & $983.66 \pm 41.10^{\mathrm{bcde}}$ & $37.51 \pm 5.19^{\mathrm{cd}}$ \\
Holland & $996.61 \pm 151.64^{\mathrm{bcd}}$ & $55.31 \pm 27.77^{\mathrm{ab}}$ \\
Sweet Charlie & $861.13 \pm 82.11^{\mathrm{ef}}$ & $30.92 \pm 5.35^{\mathrm{d}}$ \\
Aerut & $1109.51 \pm 154.29^{\mathrm{bc}}$ & $52.45 \pm 5.99^{\mathrm{abc}}$ \\
Earlibrite & $1124.67 \pm 85.13^{\mathrm{b}}$ & $51.51 \pm 5.08^{\mathrm{abc}}$ \\
\hline
\end{tabular}

Note: Figures followed by the same letter in a column indicate no significant difference in DMRT test at a significant level of $0.05 \%$. (Bold number: cultivar with the highest thickness: Underlined number: cultivars with the lowest thickness). 
Observations were also performed on the strawberry stem composed of epidermis, cortex and stele, which consists of the vascular tissues and medulla (Figure 9).

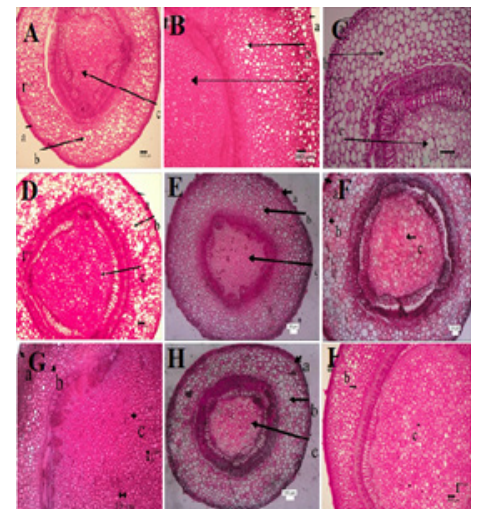

Figure 9. Cross-section of the stems of Fragaria spp. of cultivars (A) Californica, (B) Rosa Linda, (C) Berastagi, (D) Festival, (E) Santung, (F) Holland, (G) Sweet Charlie, (H) Aerut and (I) Earlibrite with constituent tissues of (a) epidermis, (b) cortex and (c) the stele. Bar scale bar: $100 \mu \mathrm{m}$

Table 2. Mean Anatomical Structure of Stems of Nine Strawberry Cultivars

\begin{tabular}{lccc}
\hline Character Cultivar & Stem Diameter & $\begin{array}{c}\text { Size of Cortical } \\
\text { Cells }\end{array}$ & Size of Stele Cells \\
\hline Californica & $3001.15 \pm 170.29^{\mathrm{b}}$ & $89.69 \pm 15.03^{\mathrm{a}}$ & $66.26 \pm 10.19^{\mathrm{ab}}$ \\
Rosa Linda & $2298.28 \pm 267.16^{\mathrm{c}}$ & $77.82 \pm 11.35^{\mathrm{cd}}$ & $63.58 \pm 10.24^{\mathrm{bc}}$ \\
Berastagi & $1478.67 \pm 121.96^{\mathrm{d}}$ & $54.45 \pm 18.43^{\mathrm{bcd}}$ & $40.97 \pm 18.16^{\mathrm{d}}$ \\
Festival & $3439.56 \pm 329.25^{\mathrm{a}}$ & $95.69 \pm 21.52^{\mathrm{d}}$ & $68.04 \pm 19.87^{\mathrm{ab}}$ \\
Santung & $2054.79 \pm 143.42^{\mathrm{e}}$ & $59.46 \pm 10.69^{\mathrm{bcd}}$ & $39.52 \pm 7.98^{\mathrm{cd}}$ \\
Holland & $2014.18 \pm 264.59^{\mathrm{e}}$ & $67.91 \pm 12.89^{\mathrm{ab}}$ & $47.95 \pm 14.12^{\mathrm{cd}}$ \\
Sweet Charlie & $2451.84 \pm 56.65^{\mathrm{e}}$ & $102.23 \pm 7.6^{\mathrm{d}}$ & $89.14 \pm 3.74^{\mathrm{a}}$ \\
Aerut & $2538.05 \pm 101.16^{\mathrm{e}}$ & $92.09 \pm 13.41^{\mathrm{abc}}$ & $73.75 \pm 10.58^{\mathrm{ab}}$ \\
Earlibrite & $2107.72 \pm 60.71^{\mathrm{e}}$ & $99.38 \pm 18.71^{\mathrm{abc}}$ & $88.17 \pm 16.72^{\mathrm{a}}$ \\
\hline
\end{tabular}

Note: Numbers followed by the same letter in a column indicate no significant difference in DMRT test at a significant level of $0.05 \%$. (Bold number: cultivar with the highest thickness: underlined column; cultivars with the lowest thickness).

Table 2 showed a significant difference in which cultivars with moderate diameter of stem being Berastagi, Festival, Holland and Earlibrite while others with a large diameter of roots. The cultivar with the largest diameter of stem wasFestival $(3439.56 \mu \mathrm{m})$, while the smallest one was Berastagi $(1478.67 \mu \mathrm{m})$. The same results were also shown by the measurement of cortical cells in which Berastagi cultivar had a large size of cortical cells $(99.38 \mu \mathrm{m})$. This may occured due to the fact that the number of cells making up the cortex of Earlibrite cultivar was smaller than that of other cultivars; thus, despite the moderate size of cortical cells, it had the same diameter as other cultivars. The larger the size of the cells making up the stem, the larger diameter of the stem is.

Observations of the leaves of strawberry plants showed that it was composed of mesophyll, upper epidermis, lower epidermis, hypodermis and vascular tissues. Mesophyll was flanked by adaxial and abaxial epidermis, composed of palisade parenchyma and spongy parenchyma. The section was dominated by chlorenchyme, the chlorophyll-containing parenchyma (Figure 10).

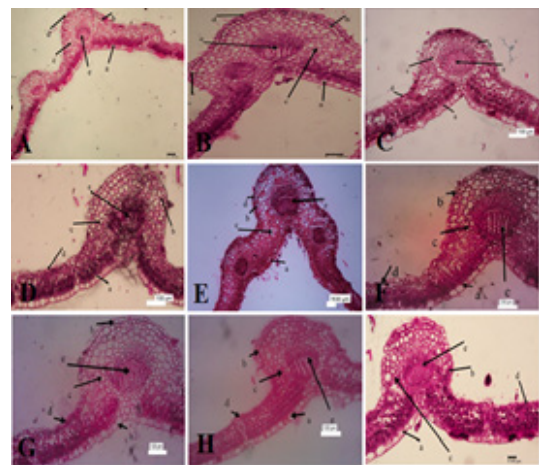

Figure 10. Cross-section of the leaves of Fragaria spp. of cultivars (A) Californica, (B) Rosa Linda, (C) Berastagi, (D) Festival, (E) Santung, (F) Holland, (G) Sweet Charlie, (H) Aerut and (I) Earlibrite, with constituent tissues of (a) upper epidermis, (b) hypodermis, (c) mesophyll, (d) lower epidermis and (c) vascular tissues. Bar scale: 100 $\mu \mathrm{m}$

Table 3 showed the cultivar with the thickest mesophyll is Festival $(356.57 \mu \mathrm{m})$, and the cultivar with the thinnest mesophyll was Aerut $(241.82 \mu \mathrm{m})$. The cultivar with the thickest lower epidermis is Holland $(48.01 \mu \mathrm{m})$, and the culti- 
var with the thinnest lower epidermis is Santung (14.76 m). Measurement of epidermal thickness showed a low variation, in which the cultivar with the thickest upper epidermis was Holland $(16.45 \mu \mathrm{m})$, and the cultivar with the thinnest upper epidermis was Berastagi $(10.41 \mu \mathrm{m})$. Measurement of the thickness of the vascular tissues also showed that the cultivar with the thickest vascular tissues was Holland $(235.96 \mu \mathrm{m})$, and the cultivar with the thinnest vascular tissues was Earlibrite $(165.52 \mu \mathrm{m})$.

Measurement of hypodermal thickness showed that the cultivar with the thickest hypoderm was Rosa Linda (32.99 m) and the cultivar with the thinnest hypoderm was Santung. Hypodermis is the tissue occurring between the mesophyll and epidermis and has no chlorophyll.

Results of the present study indicated that all nine cultivars of strawberries showed significant variations in the anatomical characters even within the same species. The variations are thought to be due to environmental influences, such as temperature, altitude, humidity, soil type and soil conditions. Murti et al. (2012) stated that phenotypic appearances could be controlled by the genetic properties of the plant itself, which are the responses to the interaction with environmental factors. This was due to the effects of domestication of strawberry plants, which are originally commonly grown in a sub-tropical climate but grown in Indonesia with a tropical climate and different environmental factors. For example, different light intensities produce plants with different characters, where high light intensities generate high photosynthetic products, thus leading to changes, such as changes in the anatomical structure with thicker mesophyll tissue for translocation of photosynthetic products, thus the leaves becoming thicker and the number of trichomes found on the upper surface of the leaf becoming fewer and even absent (Rofhl, 1992).

\section{Phylogenetic Relationships}

The present study analyzed the phylogenetic relationsships among nine strawberry cultivars using the cluster analysis method. An analysis of principal components was carried out to determine the role of each cluster in the grouping of cultivars. The 47 characters were scored using the method of Multi-State Characters. The dendogram of cluster analysis was generated by calculating the Gower General Similarity Coefficient and the UPGMA (Unweighted Pair Group Method with Arithmetic Mean) clustering technique.

Table 3. Anatomical Structure of Leaves of Nine Strawberry Cultivars

\begin{tabular}{lccccc}
\hline Character Cultivar & Mesophyll Thickness & Epidermal Thickness & Vascular Tissue Thickness & Lower Epidermal Thickness & Hypodermal Thickness \\
\hline Californica & $244.70 \pm 40.47^{\mathrm{b}}$ & $14.16 \pm 5.31^{\mathrm{b}}$ & $127.39 \pm 15.00^{\mathrm{c}}$ & $32.29 \pm 8.31^{\mathrm{bcd}}$ & $22.91 \pm 9.54^{\mathrm{ab}}$ \\
Rosa Linda & $269.90 \pm 33.59^{\mathrm{b}}$ & $21.41 \pm 8.80^{\mathrm{a}}$ & $169.83 \pm 45.99^{\mathrm{bc}}$ & $42.49 \pm 9.66^{\mathrm{ab}}$ & $32.99 \pm 13.78^{\mathrm{a}}$ \\
Berastagi & $257.29 \pm 59^{\mathrm{b}}$ & $10.41 \pm 2.47^{\mathrm{b}}$ & $177.61 \pm 29.77^{\mathrm{b}}$ & $37.55 \pm 7.29^{\mathrm{abc}}$ & $17.39 \pm 4.48^{\mathrm{b}}$ \\
Festival & $356.57 \pm 67.46^{\mathrm{a}}$ & $15.35 \pm 4.51^{\mathrm{ab}}$ & $203.48 \pm 39.3^{\mathrm{b}}$ & $36.37 \pm 7.68^{\mathrm{abc}}$ & $24.71 \pm 8.47^{\mathrm{ab}}$ \\
Santung & $320.72 \pm 32.99^{\mathrm{ab}}$ & $10.85 \pm 4.09^{\mathrm{b}}$ & $184.34 \pm 13.15^{\mathrm{b}}$ & $23.55 \pm 12.26^{\mathrm{d}}$ & $14.76 \pm 4.79^{\mathrm{b}}$ \\
Holland & $307.31 \pm 28.24^{\mathrm{ab}}$ & $16.45 \pm 4.59^{\mathrm{ab}}$ & $235.96 \pm 21.06^{\mathrm{a}}$ & $48.07 \pm 7.33^{\mathrm{a}}$ & $23.83 \pm 6.90^{\mathrm{ab}}$ \\
Sweet Charlie & $251.71 \pm 21.00^{\mathrm{b}}$ & $13.45 \pm 2.48^{\mathrm{ab}}$ & $179.66 \pm 16.22^{\mathrm{b}}$ & $31.57 \pm 4.21^{\mathrm{bcd}}$ & $21.45 \pm 4.05^{\mathrm{ab}}$ \\
Aerut & $241.82 \pm 27^{\mathrm{b}}$ & $14.38 \pm 5.8^{\mathrm{ab}}$ & $168.95 \pm 14.6^{\mathrm{bc}}$ & $29.01 \pm 6.87^{\mathrm{cd}}$ & $19.89 \pm 5^{\mathrm{b}}$ \\
Earlibrite & $250.39 \pm 40.32^{\mathrm{b}}$ & $16.00 \pm 3.41^{\mathrm{bb}}$ & $165.52 \pm 15.21^{\mathrm{bc}}$ & $31.15 \pm 3.76^{\mathrm{bcc}}$ & $22.29 \pm 3.60^{\mathrm{ab}}$ \\
\hline
\end{tabular}

Note: Numbers followed by the same letter in a column indicate no significant difference in DMRT test at a significant level of $0.05 \%$. (Green column: cultivar with the highest thickness; yellow column; cultivars with the lowest thickness). 


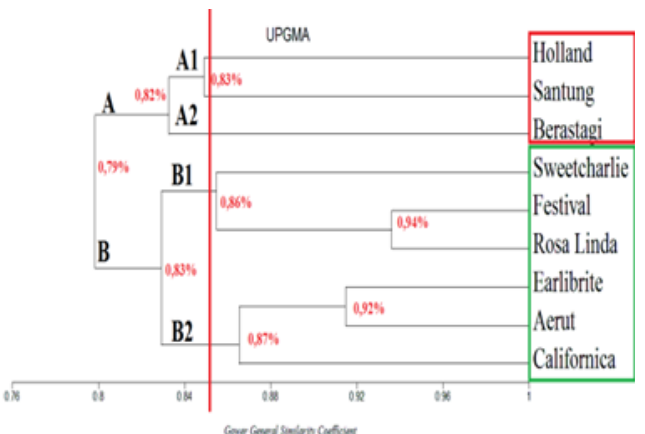

Figure 11. Dendogram of phylogenetic relationships of nine cultivars of strawberries

Dendogram showed that there are two main types, cluster A and cluster B (Figure 11). Cluster A diverged into two clusters, A1 consists of cultivars Santung and Holland and cluster A2 consists of cultivar Berastagi; those clusters converge at a distance of $84 \%$. Cluster B converges at a distance of $83 \%$, diverged into two clusters, B1 consists of Festival, Rosa Linda, Sweet Charlie, and B2 consists of Earlibrite, Aerut and Californica. Combination of characters that determine the formation of the two clusters $\mathrm{A}$ and $\mathrm{B}$ are the fruit shape, external color of the fruit, attachment of the flower, size of the petals and thickness of the hypodermal cells. Cluster A has ovoid-conic fruits, moderately bright fruits and freely attached flowers. Cluster B has ovoidcylindrical fruits with moderately bright fruits and dominantly stacked attachment of the flowers. According to Singh (1999), members of each cluster will converge into a specific cluster based on the score of similarity index of the member of the cluster; the higher the score of the similarity index, the more closely related it is. Dendogram indicated that Holland and Santung cluster on a degree of similarity of $85 \%$, while Berastagi diverged from those two cultivars at a degree of similarity of $84 \%$ of combination of the same characters, so that the three groups cluster belongs to one cluster. Those three cultivars have an intermediate type of growth and rounded leaf base. Combination of characters that diverged Berastagi from two cultivars (Holland and Santung) were attachment direction of petals, fruit shape and core color. Holland and Santung had moderate attachment direction of petals, ovoid fruits and white core, while Berastagi had an upward attachment direction of petals, conical fruits and pink core. Combination of the same characters that clusters Sweet Charlie, Festival, Rosalinda, Earlibrite, Aerut and Californica crenate leaf edges, equal attachment of the petals to the fruit, and bright red core on the fruit.

Additionally, dendogram also showed Festival at the same clusters with Rosa Linda with the highest index of similarity of $94 \%$, but they were not clustered with Earlibrite, all of which having the elder Rosa Linda; however, both cultivars clustered with Earlibrite into cluster B with a similarity index of $83 \%$. Chandler (2000) argued that 'Earlibrite' is a cultivar originating from a crossbreeding between Rosa Linda and FL 90-38 in a study conducted in Florida, while Festival is a crossbreeding between Rosa Linda and 'Oso Grande'. The characters diverging Festival, Rosa Linda and Earlibrite are the fruit shapes, size of the petals, stem diameter and thickness of the lower epidermis. On the other hand, Sweet Charlieat the same clusters with Rosa Linda and Festival at a degree of similarity of $85 \%$. Dendogram also indicated that Earlibrite more closely clustered with Aerut at a similarity index of $87 \%$.

In this study, besides using cluster analysis, the nine strawberry cultivars were also analyzed by the ordination technique (Principle Component Analysis) to determine the role of each character. In the present study the character considered as influential is the character with Eigen value of $\geq 0.2$. Results of the principal component analysis showed that there were 16 charac- 
ters that distinguish the nine strawberry cultivars. Those characters were the type of growth, growth density, fruit shape, external color of the fruit, attachment of a crown to the flowers, size of the petals, core color, location of attachment of the calyx to the fruit, root diameter, size of the cortical cells of the root, stem diameter, size of the cortical cells of the stem, size of the stele cells of the stem, thickness of the upper epidermis, thickness of the lower epidermis and thickness of the hypodermis. The 16 characters converged to form a combination that distinguished nine strawberry cultivars.

The combination of clusters on the dendogram based on anatomical and morphological characters supported phylogenetic relationships as indicated on the dendogram. Clustering of anatomical and morphological characters largely followed the pattern of divergence of varieties. In the hierarchy of classification, the higher the degree of similarity related with the closer the phylogenetic relationship. A taxon is considered to be a genus when it has a similarity index of $\geq$ $65 \%$ and $\geq 85$ for the species (Singh, 1999).

Results of cluster analysis showed that variations in characters among strawberry cultivars based on morphological characters are higher than that based on anatomical characters. It may occur due to environmental influences that lead to the morphological variations of strawberry cultivars.

Figure 12 is formed from the Eigen values of characters in a vector form. Notes to characters in the diagram are shown in Appendix 1. Calculation results of the distribution of nine cultivars of strawberries showed that cluster A (Holland, Berastagi, Santung) diverged from cluster B (Californica, Rosa Linda, Festival, Sweet Charlie, Aerut and Earlibrite), caused by fruit shape, external color of the fruit, attachment of the flower, size of the petals and thickness of the upper epidermal cells. The characters distinguishing the nine cultivars observed were the type of growth and fruit shape.

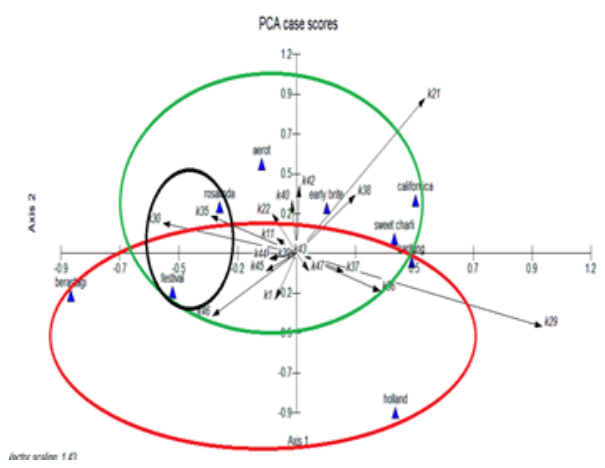

Figure 12. Distribution of nine cultivars of strawberries based on anatomical and morphological analysis

Genetic variations may occur due to several evolutionary forces, such as migration, mutation and genetic drift. In Hummer (2009) argued that migration occurs when individuals of a population move to other populations and there is interbreeding with individuals in the receiving population. Thus, strawberry plants that are native to Europe with the sub-tropical habitat are subject to phenotypic changes, such as the fruit shape as a form of adaptation, when planted in Indonesia.

Table 4. Distance matrix of cluster analysis based on anatomical and morphological characters

\begin{tabular}{|c|c|c|c|c|c|c|c|c|c|}
\hline & A & B & C & D & $\mathrm{E}$ & $\mathrm{F}$ & G & $\mathrm{H}$ & I \\
\hline A & 1.000 & & & & & & & & \\
\hline$B$ & 0.805 & 1.000 & & & & & & & \\
\hline$C$ & 0.738 & 0.787 & 1.000 & & & & & & \\
\hline$D$ & 0.784 & 0.936 & 0.809 & 1.000 & & & & & \\
\hline$E$ & 0.83 & 0.763 & 0.823 & 0.784 & 1.000 & & & & \\
\hline $\mathrm{F}$ & 0.764 & 0.8 & 0.842 & 0.864 & 0.849 & 1.000 & & & \\
\hline $\mathrm{G}$ & 0.809 & 0.844 & 0.759 & 0.865 & 0.851 & 0.76 & 1.000 & & \\
\hline $\mathrm{H}$ & 0.865 & 0.812 & 0.787 & 0.833 & 0.823 & 0.757 & 0.844 & 1.000 & \\
\hline I & 0.865 & 0.855 & 0.787 & 0.876 & 0.865 & 0.842 & 0.844 & 0.915 & 1.000 \\
\hline
\end{tabular}

Note: (A) Californica, (B) Rosa Linda, (C) Berastagi, (D) Festival, (E) Santung, (F) Holland, (G) Sweet Charlie, (H) Aerut, (I) Earlibrite 


\section{CONCLUSION}

There were 37 anatomical and morphological characters that play a role in the characterization of nine cultivars ( 25 synthetic characters and 12 diagnostics characters). Earlibrite and Aerut were closely related cultivars with a similarity index of 86\%, and so did Festival and Rosa Linda with a similarity index of $94 \%$. Of the 47 characters, shape of the fruit and type of attachment of the flowers were the main characters distinguishing among the nine cultivars studied.

\section{REFERENCES}

Budiman, S., dan D., Saraswati. 2005. Berkebun Stroberi Secara Komersial. Penebar Swadaya: Jakarta.17-23 p.

Chandler, C.K., Legard. D.E., Dunigan, D.D., Crocker, T.E., Sims, C.A. 2000. Earlibrite Strawberry. Digital Commons. University of Nebraska-Lincoln

Esau, K. 1977. Anatomy of Seed Plants. John Wiley and sons. New York. 129-131 pp.

Hancock, J.F. 1999. Strawberries. Crop Production Science in Holticulture. CABI Publishing. USA.

Hofer, Monika, R. Drewes-Alwarez, P. Scheewe \& K. Olbricht. 2012. Morphological evaluation of 108 strawberry cultivars- and consequences for the use of descriptors. Journal of Berry Research 2: 191-206.

Hummer, K. E \& J. Jannick. 2009. Rosaceae: taxonomy, Economic Importance, Genomic. Springer. UK.

IBPGR. 1986. Strawberry descriptors (Fragaria L.) International Board for Plant genetic resources. Rome.

Mauseth, J.D. 1988. Plant Anatomy. The Benjamin Cummings Publishing Company, Inc. California. USA. 34 p.

Murti, R.H., H.Y. Kim and Y.R. Yeoung, 2012. Morphological and anatomiscal characters of ploidy mutants of strawberry. Int. J. Agric. Biol. 14: 204-210.

Naseri, M.M., Tantawy, M.E. 2003/ A Contribution to the Achene Knowledge of Rosoidae (Rosaceae) LM and SEM: International Journal of Agriculture \& Biology 5(2):-.

Nielsen JA, Lovell PH (2000). Value of morphological characters for cultivar identification in strawberry (Fragaria ananassa): New Zealand Journal of Crop and Horticultural Science 28:89-96.

Region, N. 2013. The Mid-Atlantic Berry Guide. Penn State Cooperative Extension. Atlantic. 49-50 pp.

Rohlf, J.F. 1992. Numerical Taxonomy and Multivariate Analysis System.Version 1.70. NTSYS-pc Manual Book, Applied Biostatistics. NewYork.

Rukmana, R. 1998. Stroberi, Budidaya dan Pascapanen. Kanisus: Yogyakarta.
Ryall M. and Lipton. 1972. Tomatoes commodity requirements of ryie fruits handling. Transportation and storage of fruit and vegetables. West point Connecticut. The AVI Publ. Con. Inc.

Santosa, A.A. 2011. Pengelolaan Pembibitan Stroberi Di Vin's Berry Park, Cisarua, Bandung Barat, Jawa Barat. Naskah Skripsi. Fakultas Pertanian. Institut Pertanian Bogor. Bogor. 6p.

Simon, I., E. Racz and J.M. Zatyko, 1987. Preliminary notes on somaclonal variation of strawberry. Fruit Sci. 14: 154-155.

Singh, G. 1999. Plants Systematics. Science Publisher. New York. $561 \mathrm{p}$.

Sutikno. 2014. Petunjuk Praktikum Mikroteknik Tumbuhan. Fakultas Biologi UGM. Yogyakarta.

UPOV. 2012. Guidelines for the conduct of tests for distinctness, uniformity and stability (Strawberry). International Union for The Protection of New Varieties of Plants. Geneva. 1-29 pp. 